\title{
Sustainable coffee supply chain management: a case study in Buon Me Thuot City, Daklak, Vietnam
}

\author{
Giang N. T. Nguyen ${ }^{1}$ and Tapan Sarker ${ }^{2^{*}}$
}

\begin{abstract}
This paper aims to analyze and discuss the evolution towards sustainable coffee supply chain and its management in Vietnam. Coffee is a major agricultural export commodity of Vietnam with the export value accounts for 3\% of national GDP in 2014 and provides a livelihood for approximately 2.6 million people. However, the sector is facing enormous challenges as the current farming methods and processing infrastructure have been unsustainable resulting in many catastrophic impacts on the environment such as deforestation and soil degradation that have the potential to lead to a decrease in the quality of coffee beans. Using a case study in Buon Me Thuot City, Daklak, Vietnam, the paper analyses the key factors influencing the sustainable coffee supply chain management in Vietnam. Our analysis confirms that although productivity is high, and farmers have positive experiences in this sector, sustainability issues are emerging. For instance, the farmers have experienced soil erosion and a lack of water and as such are now more willing to incorporate sustainability initiatives in their production and processing.
\end{abstract}

Keywords: Coffee supply chain, Sustainability, Case study, Vietnam

\section{Introduction}

Coffee is a major agricultural export commodity of Vietnam with the export value accounts for 3\% of national GDP in 2014 and provides a livelihood for approximately 2.6 million people (Vietnam Customs 2015). Following Brazil, since 2000 Vietnam has continuously been the world's second-largest exporter of coffee, typically to EU and US markets, which shows a positive outlook for the future of this sector (Marsh 2007). However, numerous challenges need to be overcome in order to make it happen. Currently, less than 10\% of Vietnamese coffee is grown sustainably, compared with $75 \%$ in Latin America (Mistiaen 2012). With the increase in global market requirements, the competitiveness of Vietnamese coffee is being threatened. For example, people still use many unsustainable farming methods such as monocultures, burning of crop residue, poor fertility management, tillage, etc. which results in many catastrophic impacts on the environment - such as deforestation and soil degradation - have the potential to lead to a

\footnotetext{
* Correspondence: tapan.sarker@griffith.edu.au

${ }^{2}$ Griffith Business School, Griffith University, Brisbane, Queensland, Australia Full list of author information is available at the end of the article
}

decrease in yields, increase in insect pests and diseases on crops (Schmitter et al. 2010). Many researches confirms that the rural poor dwellers are one of the most vulnerable residential group to environmental deterioration as their livelihoods mainly depend on natural resources (Dasgupta et al. 2003). A meta-analysis of (Rahmann 2011; Bennett and Franzel 2013) states that the level of biodiversity in sustainable farms (such as organic farms, fair-trade farms) is higher than conventional farms. Sustainable farming is cost-effective system that have significant impacts on poverty alleviation, sustainable development in under-developed nations around the world (Kilcher 2007). According to (Crowdera and Reganold 2015; Nemes 2009; Ramesh et al. 2010), sustainable farms provide farmers with higher economic profitability by 22 to $35 \%$ compare to others thanks to higher yields and price premiums of sustainable products. Therefore, sustainability will need to be comprehensively addressed in coffee production to improve the uses of natural resources for human needs without damaging the environment (Nguyen and Yapwattanaphuna 2015). Also, sustainable approach enables farmers to use their knowledge and skills more effectively. However, the 
factors impact on farmers' adoption to a new sustainable agricultural practice vary widely from farmers' perception, the characteristics of the new practice to resource endowments, socio-economic status, demographic characteristics, and access to institutional services (Negatu and Parikh 1999). The government is aiming to reach $65 \%$ of sustainable coffee production by 2018 , which will help to preserve the environment, improve the living standards of the farmers and ensure a steady coffee supply for food processors (Mistiaen 2012).

Hence, the purpose of this paper is to study the current situation of the supply chain of Vietnamese coffee in Buon Ma Thuot City, Dak Lak Province, Vietnam, to examine the issues related to the development of sustainable coffee and to build up a logistic model that will explain the correlation between those factors and the decision to join the sustainable coffee program. This study also propose some suggestions to increase the competitive advantages of the commodity, as well as to help coffee farmers to be more flexible in a constantly changing market.

This research investigates the opinions of local farmers through quantitative surveys. Qualitative interviews are also used to interview 23 local collectors and the staff of five famous large coffee manufacturing companies to provide an overview of the situation. SPSS was used to analyse the data and run the logistic regression model. The data were complemented by documentary analysis, including internal data and interview documents.

The paper provides empirical research about the sustainable supply chain in coffee farming methods in Buon Me Thuot City. The study found that although productivity is high, and farmers have positive experiences in this sector, sustainability issues are emerging. The farmers have experienced soil erosion and a lack of water. A logistic regression model is established based on the collected data to explain the relationship between the dependent variable 'Certificate ownership' and the independent variables 'Productivity', 'Local support' and 'Experience' to help sustainable coffee organisations forecast the probability of farmers obtaining a sustainability certificate in their current situation; this will help to choose promising candidates to develop sustainable programs.

The research has some limitations. For instance, it does not measure the financial benefits of sustainable coffee; therefore, future research should focus more on the financial aspects of sustainable coffee farming. Nevertheless, the paper helps to consolidate the position of the Vietnamese coffee brand on the international market, to improve the livelihood of famers and to conserve the environment in Vietnam and will help fulfil the goal of improving the supply chain of Vietnamese coffee to develop sustainable practices.

\section{Literature review: Sustainable supply chain management}

Interest in sustainable supply chain management has increased significantly in both academic research and industrial practices since the minimisation of the adverse impacts of human activities and the maintenance of sustainable social development have become central concerns globally (Beamon 1999; Prokesch 2010). First, sustainability is defined as the capability to meet current demands without compromising the ability of future generations to meet their needs (World Commission on Environment and Development 1987). Linking the three pillars of sustainability and supply chain management means managing a complete supply chain life-cycle, from product design, procurement, logistics, knowledge management, marketing, and operations to return and disposal, with the explicit considerations of sustainable development factors such as economic, environmental and social elements (Kolk and Tulder 2010; Morali and Searcy 2012). A sustainable supply chain is essential for competitiveness with regard to price, quality, dependability, flexibility and responsiveness (Markley and Davis 2007).

Over the last few decades, many companies have put notable financial investment in socially and environmentally responsible business but the real contribution of these investment to the economic performance has been a matter of controversy (Carter and Easton 2011; Hoejmose and Adrien-Kirby 2013). Zhu and Sarkis (2007) pointed out that the implementation of sustainable supply chain management is mostly because of external pressures such as regulatory requirements, customer interests or competitive reasons irrespective of little financial return. Moreover, other issues in supply chains such as price competition and responsiveness are matters of the utmost importance, sustainable supply chain adoption is a challenging strategy (Mohd 2010). However, Wang and Sarkis (2013) showed that the implementation of sustainable supply chain management might not receive a reward immediately, but the corporate financial performance might be improved after two years. Carter (2005) also stated that socially responsible practices may not have direct impact on organizational cost performance, but influence the relationship management indirectly. It can bring higher customer satisfaction, innovation, efficiency, trust, flexibility and environmental conservation, as well as better living standards (Ageron et al. 2012; Brammer et al. 2011). Moreover, a rising number of significant issues on sustainability and sustainable supply chain management have been seen as impacting on the enterprise's upstream relationships (Beske et al. 2006) and its downstream customer satisfaction (Ageron et al. 2012). Besides, in the coming years when environmental 
standards and international legislations become stricter, businesses may benefit significantly from the adoption of sustainable supply chain such as waste minimization, green product design, and technology cooperation. And thus, the integrating sustainability into supply chain may prove to be an effective strategy in the future to secure the business.

In today's world agriculture has to be more intensive to feed a booming world population. The detrimental impacts of conventional agriculture can be widely known including water pollution, land degradation, soil erosion, an increase in pest resistance, pesticide drift and diffusion throughout the food chain and ecological equilibrium disruption (Altieri and Koohafkan 2008). Productivity has no longer been seen as a solely metric to evaluate agricultural development. Sustainable agriculture has been gaining significant attention from farmers, policy makers and consumers worldwide (Theocharopoulos et al. 2012). Sustainable agricultural supply chain management can be understood as managing resources and risks to create a more effective, efficient and productive supply chain network in order to produce more valuable and competitive agriculture commodities from the same land area while reducing negatively environmental impacts and increasing contributions to environmental improvements and the development of societies (Pretty et al. 2011). Furthermore, cross-border supply chains are admittedly becoming increasingly popular in agriculture. Local famers in developing countries have connections with traders in developed countries to sell their products at higher prices, achieving a vertical cross-border supply chain network (Jaffee and Siegel 2008). Cross-border supply chains not only make profit for individuals or separate companies, but can also stimulate the development of local agriculture, boost the economy, reduce the unemployment rate, develop the sustainability of the societies and environment, and secure global food security (Roekel et al. 2002). However, when a cross-border supply chain becomes more popular in the agricultural sector, the supply chain will experience increasing risks such as policy and institutional related risk, operational managerial related risks. For this reason, managing a sustainable supply chain is vital in order to maintain long-term business relationships and stabilise the economic development of the world (Farina and Reardon 2000).

Moreover, (Sarkis et al. 2011; Font et al. 2008) confirmed that sustainable supply chain management literature derived from several organizational theories including complexity theory, population ecology theory, information theory, institutional theory (Aguilera and Jackson 2003; Maignan and Ralston 2002), resource based view (RBV) (Bowen et al. 2001; Carter and Rogers 2008), resource dependence theory (RDT) (Carter and Rogers 2008), social network theory, stakeholder theory, and transaction cost economics (Carter and Rogers 2008).

Due to the nature of this research, the literature of this paper is mostly based on institutional theory, resourcebased view (RBV) theory and stakeholder theory. In terms of institutional theory, it explained how institutional factors, such as regulation, 'collective industrial self-regulation', NGOs and other independent organizations can influence organizations to interact with their stakeholders and behave in socially responsible manners and avert socially irresponsible actions (Campbell 2007). Institutional theory facilitates the ability to understand the variance in interactions amongst various stakeholders and corporate governance in different situations (DiMaggio and Powell 1983; Matten and Moon 2008). Besides that, stakeholder theory suggest that internal and external parties exert pressure on firms to change organizational practices in order to eliminate negative impacts promote positive ones (Freeman 1984). Therefore, stakeholder theory may explain how stakeholders can put pressure on firms to implement sustainable supply chain management practices which are initially economically disadvantageous (Sarkis et al. 2011). Regarding to the resource-based view (RBV) theory, (Barney 1991) indicated that a firm have to manage valuable, rare, imperfectly imitable, and non-substitutable (VRIN) resources in order to generate sustained competitive advantages. There is also a positive correlation between VRIN resource management and vertical integration in the supply chain (Pfeffer and Salancik 1978; Sarkis 2009). Therefore, this research aims to examine the impacts of institutional factors, stakeholders' pressures and the scarce of resources on sustainable coffee supply chain management practice in Vietnam.

\section{The introduction of certified sustainable coffee}

This paper aims to investigate the management of the sustainable coffee supply chain. According to (Giovannucci and Koekoek 2003), sustainable production practices are the best solution to improve the situation and bring better quality coffee to customers. Sustainable production is a relatively new initiative for the coffee industry, but growing numbers of customers are willing to purchase certified sustainable coffee. There are also significant benefits for approximately three quarters of a million farm households around the world and society more generally. Certified coffees are currently defined as those that consider at least one aspect of sustainability, including farming in a good-quality environment, providing economically viable for farmers and promoting social equity among farmers and workers (Giovannuccia and Ponte 2005). It helps stakeholders in the coffee supply chain network to preserve the 
environment, appreciate human and social rights, and offer customers traceable and high-quality products (Wahyudi and Jati 2012). The certifications for sustainable coffee are verified by third-party auditors to ensure that coffee is produced in accordance with the guidelines. Producers or buyers have to pay different fees related to certification, but will receive a higher economic benefit through premiums paid when they sell their coffee (Lentijo and Hostetler 2011). Currently, the most common and famous types of certifications including Organic, Fairtrade, Rainforest Alliance, Bird Friendly, UTZ certified, Starbucks C.A.F.E Practices and 4C. General criteria for common certification programs for coffee are presented in Table 1 (Lentijo and Hostetler 2011). However, according to (Conroy 2007), the large companies in rich nations earned certificates faster and easier than small firms in developing countries due to the lack of support infrastructure, high costs of certification, annual auditing, and improvements. Therefore, there is a need to improve the situation.

\section{The supply chain and sustainable issues of Vietnamese coffee}

According to (TechnoServe 2013) in Vietnam, approximately $95 \%$ of coffee growers are smallholder farmers, and coffee brings highly profitable incomes for them. Moreover, Vietnamese coffee has the highest yields and the lowest farming cost in the world that means Vietnamese coffee is very potentially competitive in the world market (The Voice Of Vietnam 2014; Minot 1998; Ward and Nguyen 2014). But the high yields also result from intensive farming practices deployed with the fact of over-fertilisation for coffee tree that could lead to the very detrimental decline in the future production (Vietnam Briefing 2014).

Figure 1 illustrates the supply chain of Vietnam's coffee. In this chain, supporting industries play roles as input providers, including coffee seedling providers, plant protection sellers and fertiliser sellers.

Table 1 General criteria of common certification programs for coffee

\begin{tabular}{lllll}
\hline $\begin{array}{l}\text { Certification } \\
\text { Seal }\end{array}$ & $\begin{array}{l}\text { Environmental } \\
\text { Criteria }\end{array}$ & $\begin{array}{l}\text { Social } \\
\text { Criteria }\end{array}$ & $\begin{array}{l}\text { Economic } \\
\text { Criteria }\end{array}$ & $\begin{array}{l}\text { Quality } \\
\text { Standards }\end{array}$ \\
\hline Organic & $\checkmark$ & & & \\
Fairtrade & & $\checkmark \checkmark$ & $\checkmark$ & \\
Rainforest Alliance & $\checkmark \checkmark$ & $\checkmark$ & & \\
Bird-friendly & $\checkmark \checkmark$ & & & \\
UTZ Certified & $\checkmark$ & $\checkmark$ & $\checkmark$ & $\checkmark \checkmark$ \\
Starbucks C.A.F.E & $\checkmark$ & $\checkmark$ & $\checkmark$ & $\checkmark$ \\
4C & $\checkmark$ & $\checkmark \checkmark$ & $\checkmark$ & $\checkmark$ \\
\hline$\checkmark:$ Modede & & &
\end{tabular}

$\checkmark$ : Moderate criteria- $\checkmark \checkmark$ : Very Strong criteria

Source: (Lentijo and Hostetler 2011)
According to (Le 2013; D'haeze et al. 2005), although they are well experienced in planting coffee, Vietnamese farmers' lives have not been improved due to the high risk of the production environment and market conditions. The added value they gain remains the lowest in the entire chain of coffee production (Le 2013). There are some major risks faced by farmers, which could make the supply chain unsustainable. These are listed in Table 2 (Minot 1998).

Data from the (International Coffee Organisation (ICO) 2015) showed that only 9\% of total exported Vietnamese coffee is sustainable. It also revealed different challenges for coffee industry in different countries, as shown in Fig. 2.

(Jarosz 2000) as well highlighted the role of smallscale household farmers in maintaining sustainable agriculture which are the main workforce in Vietnam's coffee industry. State-owned (provincial) farms, which account for just $15 \%$ of the coffee-growing area, are organised and managed by governmental cooperation (Nguyen 2010). They produce high-quality coffee with professional farming techniques. Sustainability programs have concentrated mainly on this high-yield farmer segmentation. However, the private farms accounted for $85 \%$ of the total area operated by household farmers (less than 5 ha per household). Although they receive some support from local authorities, their farming methods are still below certification standards for coffee. Those farmers also have experienced socioeconomic inequality (Nguyen and Yapwattanaphuna 2015). Moreover, intensive use of cheap inorganic inputs and inefficient use of irrigation water have gradually resulted in soil degradation and deteriorated water quality (Zulfiqara and Zulfiqara 2017; Ali and Byerlee 2002). These issues have threatened sustainability of economic and social achievements in any areas (Zulfiqara and Zulfiqara 2017). Therefore, many problems that needs to be tackled in order to increase the production of sustainable certified coffee in Vietnam.

\section{Conceptual framework to manage the supply chain of sustainable coffee}

As mentioned in the previous part, this research is based on institutional theory, resource-based view (RBV) theory and stakeholder theory. Although triple dimensions of sustainability have been widely accepted (Acosta-Alba and van der Werf 2011), environmental and economic goals have attracted more attention (Von Wirén-Lehr 2001; Galdeano-Gómez et al. 2017), while social concerns have been neglected (Galdeano-Gómez et al. 2017). Nevertheless, triple dimensions of sustainability are concurrently considered in this research. Besides, most of the previous researches focus on sustainability at farm level because individuals are believed to be 


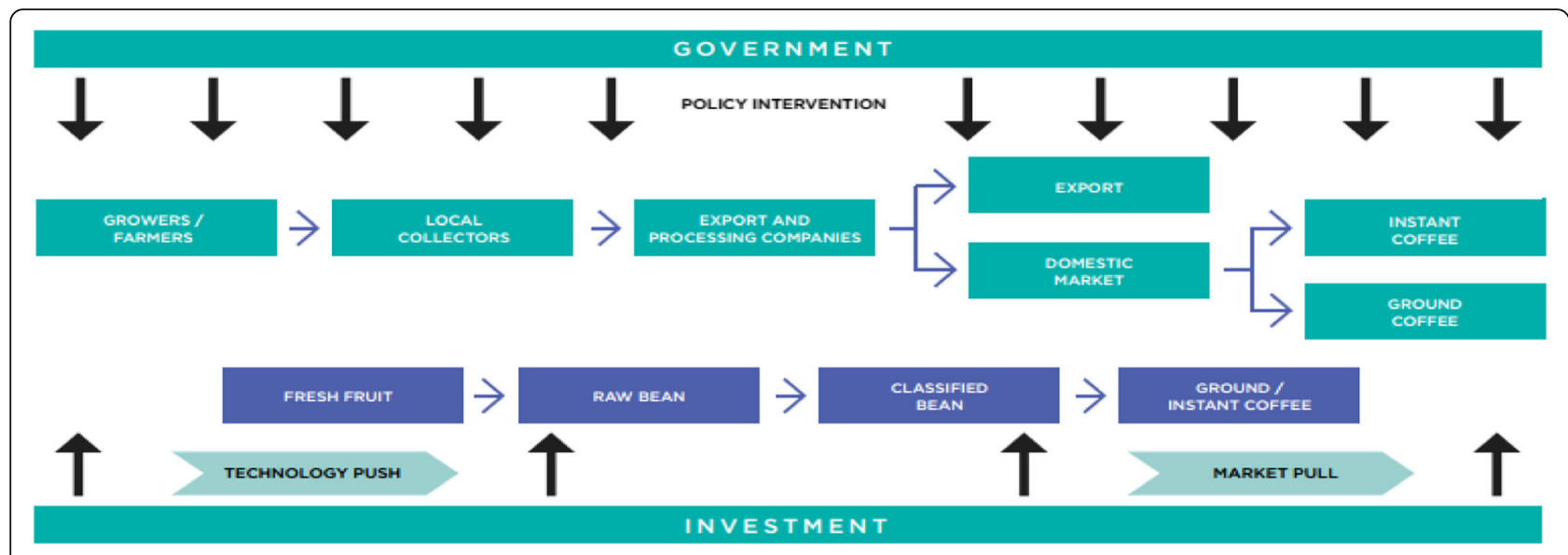

Fig. 1 General supply chain of Vietnam's coffee

responsible for making the most important decisions regarding the use of resources and new technological implementation (Webster 1999). However, as stated by (Halberg et al. 2015), the analysis should be taken from different points of view of farmers, organisations and local authorities. Thus, this research approaches the viewpoints of all related-stakeholders including farmers, coffee processing companies and coffee collectors. Similar to the work of (Iakovou et al. 2014), the research uses the methodological framework for sustainable supply chain management in agricultural business, as shown in Fig. 3. The framework helps to deal holistically with all aspects of the chain. It covers major concerns about sustainable agricultural management in terms of farming methods, environmental management, supply chain management and reverse logistics as well as marketing strategy and corporate social responsibility. This framework is then modified to fit the objectives of the

Table 2 Major risks to Vietnamese coffee supply chain

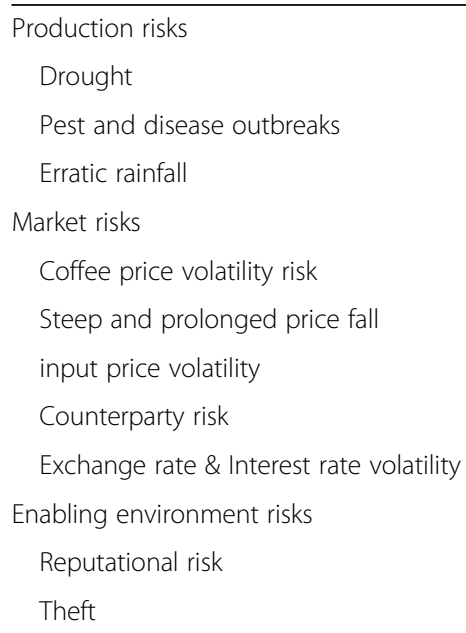

Source: (International Bank for Reconstruction and Development/ The World Bank 2011) research in Vietnamese coffee supply chain. A similar schematic framework which showed very comprehensive results is applied in the research of (Zulfiqara and Zulfiqara 2017) to evaluate agricultural sustainability in Pakistan.

Six main factors need to be focused upon to build up a sustainable supply chain network:

- Sustainable farming. This relates to the replacement of chemical pesticides and fertilisers with bio-fertilisers for weed and pest control (Hayati et al. 2010). The annual production level and farmers' income are also investigated to understand the differences between certified and non-certified coffee farms. Moreover, crop diversification is also mentioned due to its benefit of reducing risks and uncertainties arising from mono-cropping, and biological and climatic changes. All indicators above are fully assessed in the work of (Acs et al. 2005). These indicators aim to evaluate sustainability of economic and environmental pillars (Malik and Singh 2002; Chakraborty 2012).

- Supply chain management: This pays attention on the innovation of supply chain and logistics management to reduce energy consumption and control the pollution levels from the transportation and production process. The support of information systems also proves to be crucial with regard to this aspect. This aspect is presented comprehensively in the research of (Sarkis et al. 2011; Seuring and Müller 2008) and used to evaluate the economic sustainability.

- Marketing: According to Johns and Pine (2002), with the purpose of evaluating economic dimension, this focuses on pricing policies of companies for premium products; product differentiation in terms of labelling, promotion strategies, etc.; consumers' 


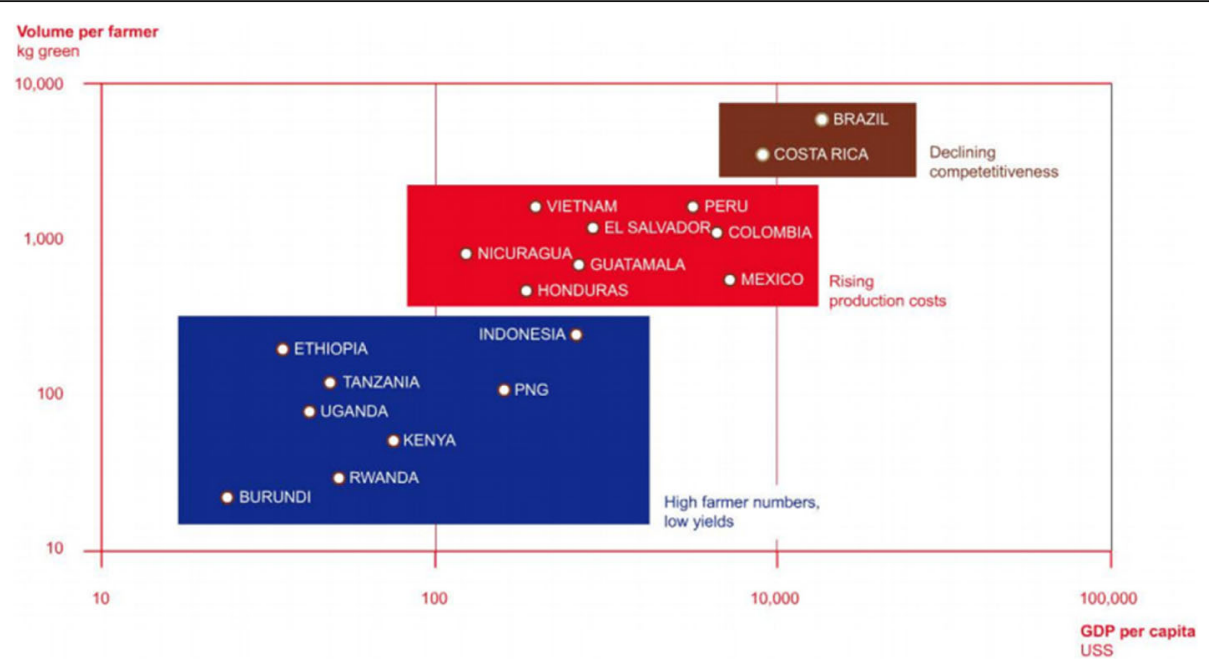

Fig. 2 Challenges of coffee industry in different areas

attitudes and awareness of sustainable products; and the strategic development of the product life-cycle.

- Environmental management: (Walker et al. 2008; Hassini et al. 2012) examined the critical factors regarding environmental management to reduce negative environmental impacts. They concentrate great attention on biodiversity; soil quality; natural resources; climate change; air and water quality; and emission reductions in production and logistics activities. The management of waste-disposal processes, controlling the source and amount of water consumption for irrigation and the use of energysaving systems could also draw a lot of attention.

- Reverse logistics: This relates to the recycle of containers, packaging materials and the use of environmentally friendly materials. The critical issues of reverse logistics are investigated through content analysis in the research of (Pokharel and Mutha 2009). Evidences of the benefits gained from reverse logistics in sustainable supply chain are presented comprehensively in (Alblas et al. 2014; Hsu et al. 2016). This measure the efficiency of economic sustainability.

- Corporate social responsibility (CSR): This concerns the harmony of using natural and local human resources to tackle inequality, poor living standards and low education levels in the rural area. Typically, this issues are studied broadly in the study of (Kong 2012; Cuganesan et al. 2010). This aspect evaluates social sustainability factor.

\section{The methodology and model Research design}

Due to the nature of the research, an empirical multiphase mixed methods approach was used to examine different perspectives of the coffee supply chain to investigate sustainability implementation and its effects on the coffee supply chain in Vietnam. A plausible explanation for this design is that different groups of interviewees require different methodologies in order to fully

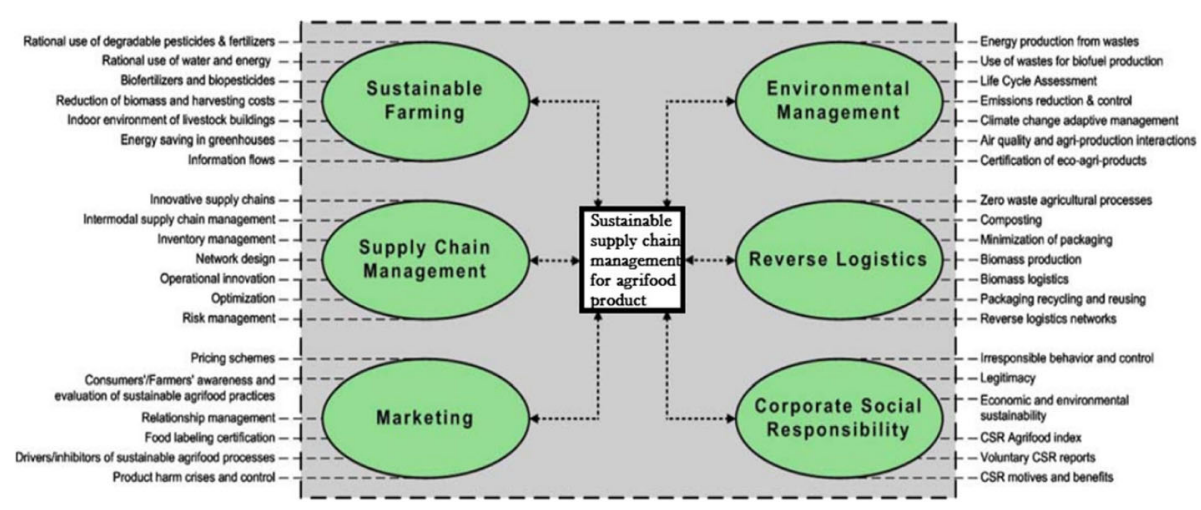

Fig. 3 Conceptual framework for sustainable supply chain management for coffee 
access the most available information and achieve the goal of the research.

\section{Qualitative research methodology}

A qualitative methodology was utilised to examine the opinions of experienced professionals in well-known coffee manufacturing companies and local coffee collectors. They have good knowledge about the research topic and high educational levels that ensure the accuracy and reliability of the responses. It helps to provide an in-depth investigation of the real impacts of sustainable certification practice on their business, which quantitative questions cannot access and evaluate precisely.

\section{Quantitative research methodology}

A quantitative methodology was utilised to examine the current circumstance of sustainable behaviours and how sustainability certification practices are measured in terms of farming methods, social security and the knowledge of sustainable coffee production by farmers. They have experience of the current situation and the basic knowledge to answer these simple and clear questionnaires. The information produced by quantitative research is then used to run the regression, and run an ANOVA analysis to check the relationships among the variables.

\section{Research population and sampling The population of the research}

The population of the research is a collection of key stakeholders including coffee farmers, local coffee collectors and five coffee manufacturing companies in Buon Ma Thuot City. The research chose Buon Ma Thuot City where is known as the capital coffee production of Vietnam, accounted for two third of total Vietnamese coffee production since 2010 (Voice of Vietnam 2017). The population excludes the participation of final customers because $95 \%$ of Vietnamese coffee production is exported to developed countries and consumption of sustainable coffee has increased significantly, as mentioned in the literature review section. Hence it is quite clear that customers show considerable support for sustainable coffee, and the development of sustainable coffee depends mainly on the collaboration of the listed stakeholders.

\section{Research sample}

To fit with the research design, the sample of the research comprised a group of private coffee farmers in Buon Ma Thuot City whose coffee is partly or wholly sold to well-known coffee processing companies and the local collectors for these farmers. It also included participants from five large coffee processing companies to examine their opinions and experience with the purpose of analysing the current sustainability practices of the coffee supply chain and identifying weaknesses in order to make improvements.

Although the size of the sample seems small, it is still representative and controllable to ensure the generalisability of the results. Most private coffee farms are planted using the same farming methods (Nguyen 2010). The companies that were examined were the major and best-known coffee processing companies in Vietnam, accounting for nearly 25\% of the market share (Ipsos Business Consulting 2013). The companies also have experience in developing certified sustainable coffee. They were awarded a UTZ Certificate for sustainable coffee cultivation in coordination with local coffee farmers in Dak Lak Province.

This is a purposive and controlled sample, so the surveyed participants needed to have a number of characteristics:

- In the interview with the coffee processing companies, interviewees had to be staff or former staff in the purchasing department or in coffee processing factories in both Ho Chi Minh City and Buon Ma Thuot City. They all had a good understanding of the supply chain network and sustainability practices in the coffee processing industry.

- The survey of farmers had to be random and include both male and female workers. The surveyed farmers could plant either sustainable certified coffee or normal coffee.

- All the surveyed coffee growers and collectors had to wholly or partly sell their product to the factories of these companies.

\section{Conceptual framework for the research}

Based on the conceptual framework mentioned in the literature review, three different interview stages were conducted.

Firstly, 200 close-ended quantitative survey questionnaires were randomly given to local coffee farmers in Buon Ma Thuot City, Dak Lak Province to investigate the current farming methods, environmental issues and social attainment in this research area. These questions were simple and required little time to finish, encouraging interviewees to complete the survey. The author strictly monitored and followed up the quantity and quality of the responses. The questionnaires concentrated mainly on current farming methods; environmental issues; social attainment and the knowledge of sustainable coffee programs of surveyed farmers. The response rate was 137 out of 200 questionnaires.

Open-ended questionnaires were then used to ask 23 experienced representatives of five major coffee processing companies and local coffee collectors about 


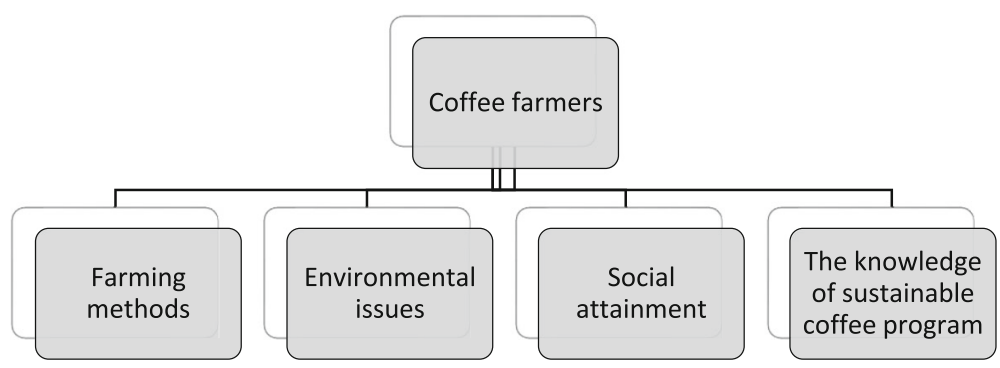

Fig. 4 Conceptual framework to interview coffee farmers. Source: Authors' own

experience and to elicit information. For the local collectors, questionnaires were focused on reverse logistics, supply chain management, corporate social responsibility and environmental management. For the coffee processing companies, questionnaires concentrated on organisational-level issues, including marketing, supply chain management; reverse logistics; corporate social responsibility (CSR); and environmental management. These frameworks are presented in Figs. 4, 5 and 6 below.

\section{Data analysis and findings}

\section{Current farming methods}

According to the survey results shown in Table 3, coffee growers in the surveyed area have considerable experience (more than 10 years) in cultivating coffee, but they are mainly small household coffee farmers $(2-5$ ha), which conforms to the previous figures in literature review. Furthermore, coffee trees in this area are mostly mature (11-20 years) - a very important factor to the productivity of crops. Moreover, the data prove the coffee farms are highly productive in comparison with the average yield of Vietnam.

However, just $43.1 \%$ (59 of 137) of surveyed farmers stated that they were currently planting shade trees to protect their farms against soil degradation. Furthermore, $57.7 \%$ of samples (79 of 137) said they were using both organic and chemical fertilisers, with only $38.7 \%$ (53 of 137) stating that they only use organic fertilisers. A total of $70.1 \%$ (96 of 137) admitted that they had used large amount of pesticides for pest control in cultivating coffee. Another figure that should be noted is nearly $60 \%$ of surveyed farmers who said they had diversified their coffee farms with other agricultural trees such as durians and avocados. Approximately half of participants (55.5\%, or 76 of 137) said they owned a coffee-hulling or roasting machine. The data also led to the finding that although there are some machinery supports for cultivation, coffee farmers still tend to use traditional farming practices to intensively cultivate their farms in order to increase the yields. They have not yet applied proper organic farming practices to maintain sustainability in their cultivation.

A Chi square test in Table 4, showed a positive relationship between certification ownership and experience of farmers, as surveyed farmers who owned sustainable coffee certificates were more likely not to be more experienced than those who did not. The statistics also showed that the productivity of experienced farmers was significantly higher than the productivity of farmers with less than 10 years' experience.

\section{Environmental management}

Turning to concerns about environmental management, as mentioned earlier, coffee growers still mainly use traditional farming practice to cultivate their farms, which can only reach higher yields but cannot achieve sustainability status. Base on the collected information, $47.4 \%$ (65 of 137) of surveyed farmer agreed that they had experienced soil erosion within the past year and

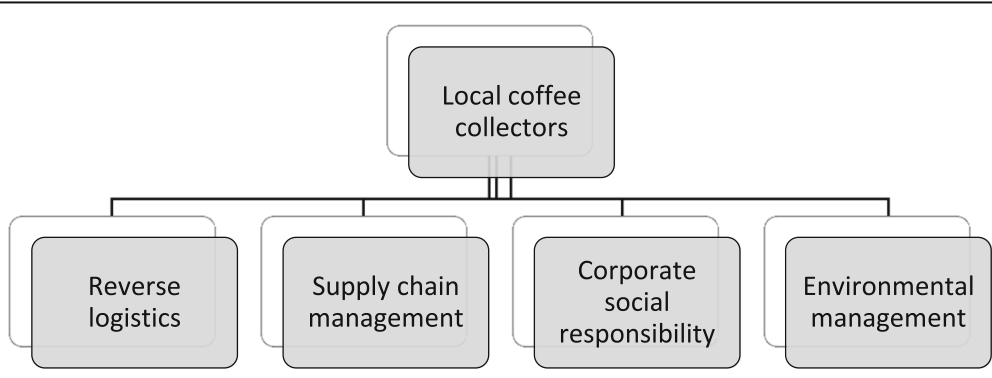

Fig. 5 Conceptual framework to interview local coffee collectors 


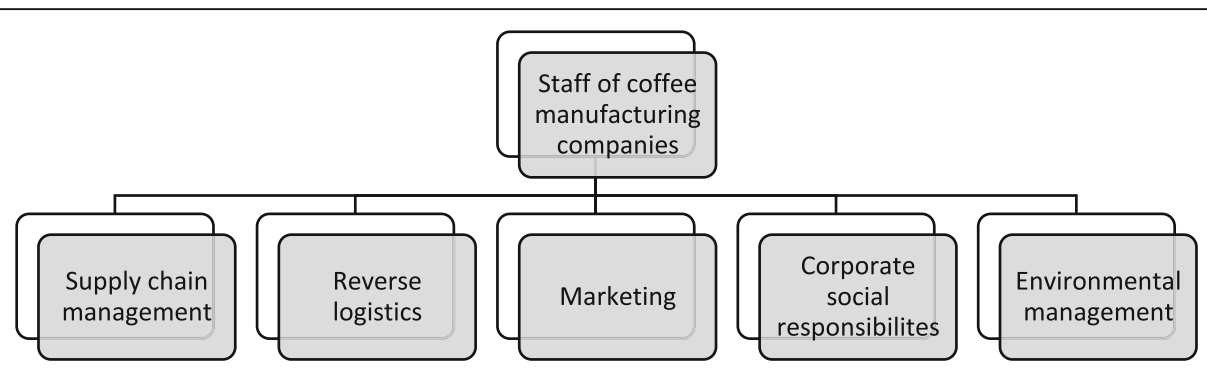

Fig. 6 Conceptual framework to interview staff of coffee manufacturing companies

65.7\% (90 of 137) of surveyed farmers said they had experienced a shortage of water for irrigation during farming times. Moreover, 73.7\% (101 of 137) of participants said they had to dispose of solid waste by themselves instead of waiting for local companies collect it, resulting in very negative effects for the environment, such as pollution and soil degradation.

According to the results of the Chi-square test shown in Tables 5 and 6 , surveyed farmers who had been granted sustainable coffee certificates were more likely not to use pesticides to control pests and to plant shade trees to protect soil from deterioration than those who did not hold such a certificate.

On the other hand, local collectors and supervisors from the coffee processing companies agreed that they did not pay enough attention to the management of waste disposal. Although it is said that processing factories strictly follow the current waste disposal instructions and regulations of the Vietnamese government, there is a failure to monitor suppliers' waste-disposal processes because of a lack of awareness of farmers and collectors. It is not even possible to control the use of fertilisers and pesticides if the farmers do not participate in any certified coffee programs and do not follow their instructions. However, they believe that if farmers and local collectors join a sustainable coffee program, their waste-disposal processes, and use of fertilisers and pest control are controlled and managed properly due to the introduction of related actors to train and educate farmers on the benefits of sustainable and safe farming practices.

\section{Supply chain management}

The information in this section is based on qualitative interview with local collectors and staff of a well-known coffee processing company. When asked, senior purchasing executives and the production supervisors of the coffee processing factory in Buon Ma Thuot City said that all the factory's products were sourced only from reliable local collectors, who had a very good relationship with the company. The company deals mainly with these collectors rather than individual farmers, although they know that purchased coffee needs to go through at least two lower tiers before them, which could increase the production cost and reduce the value for farmers. However, because of coffee growers are small household farmers, it takes more time to collect at their farms and they have to accept the need to pay more to go through intermediaries. Chi square test results show that farmers who held a sustainability certificate could more readily sell their coffee directly to coffee manufacturing companies than those who did not hold the certificate.

In addition, these senior purchasing executives also mentioned that they were trying to set up a traceability supply chain network for all coffee products, but this had not yet been put into practice. Only few premium and high quality Arabica coffee products use this system to harmonise with the requirements of certified coffee production in the project, coordinating with Utz Association. Finally, the production supervisors said they were planning to gradually change packaging of the final product from plastic materials to paper and recyclable materials up until 2020.

Table 3 Descriptive statistics about the coffee farming (data collected from the survey)

\begin{tabular}{|c|c|c|c|c|c|}
\hline & $\mathrm{N}$ & Minimum & Maximum & Mean & Std. Deviation \\
\hline Years of experience & 137 & 1.00 & 4.00 & 2.4453 & .96953 \\
\hline Total area & 137 & 1.00 & 3.00 & 1.8102 & .64777 \\
\hline Productivity & 137 & 1.00 & 4.00 & 2.4891 & 1.03694 \\
\hline The years of coffee farm & 137 & 1.00 & 3.00 & 1.7883 & .62345 \\
\hline Valid N (listwise) & 137 & & & & \\
\hline
\end{tabular}

(With years of experience: ' 1.00 ': $<5$ years, '2.00': 5-10 years, '3.00': 10-15 years, '4.00': >15 years; total area: ' 1.00 ': $<2$ ha; '2.00': $2-5$ ha; '3.00': $>5$ ha; productivity:

'1.00': < 2 tons/ha, '2.00': 2-4 tons/ha, '3.00': 4-6 tons/ha, '4.00': >6 tons/ha; and years of coffee farm: ' 1.00 ': < 10 years, '2.00': $11-20$ years, '3.00': > 20 years) 
Table 4 The relationship between productivity and years of experience

\begin{tabular}{|c|c|c|c|c|c|c|}
\hline \multicolumn{7}{|l|}{ Count } \\
\hline & & \multicolumn{4}{|c|}{$\begin{array}{l}\text { Years } \\
\text { of experience }\end{array}$} & \multirow[t]{2}{*}{ Total } \\
\hline & & $<5$ years & $5-10$ yrs & $10-20$ yrs & $>20$ years & \\
\hline \multirow[t]{4}{*}{ Productivity } & $<2$ tons/ha & 19 & 9 & 0 & 0 & 28 \\
\hline & 2-4 tons/ha & 16 & 23 & 3 & 0 & 42 \\
\hline & $4-6$ tons/ha & 1 & 2 & 20 & 16 & 39 \\
\hline & $>6$ tons/ha & 1 & 1 & 10 & 16 & 28 \\
\hline Total & & 37 & 35 & 33 & 32 & 137 \\
\hline \multicolumn{7}{|l|}{ Chi-Square Tests } \\
\hline & Value & df & Asymp. Sig. (2-sided) & & & \\
\hline Pearson Chi-Square & $1.202 \mathrm{E}^{\mathrm{a}}$ & 9 & .000 & & & \\
\hline Likelihood ratio & 143.572 & 9 & .000 & & & \\
\hline Linear-by-linear association & 81.480 & 1 & .000 & & & \\
\hline$N$ of valid cases & 137 & & & & & \\
\hline
\end{tabular}

${ }^{\mathrm{a}} 0$ cells $(.0 \%)$ have expected count less than 5 . The minimum expected count is 6.54

Local collectors are the main dealers who sell coffee bean to exporters or coffee factories, and they said they tried to find reliable coffee beans from farmers. As shown in Table 7, certified coffee farmers tended to sell more coffee directly to coffee processing companies or coffee cooperatives than uncertified coffee farmers. According to the Chi square test shown in Table 8, collectors or traders examined the planting process more often with regard to famers who held a sustainability certificate than in relation to those who did not have a certificate.

Finally, the representative of a coffee bean-collecting company commented that the logistics costs in her company were due mainly to transportation and storage. It was necessary to arrange different collection times for each farm as the harvest times varied considerably from farm to farm. Everything the farmers did to improve practices relied on experience, as they had not yet attended any training to optimise their operations.

\section{Reverse logistics}

For the reverse logistic issues, data were analysed based on the opinions in the interviews about the current situation. Local collectors said they just improved their work by experience; there was no training to assist them with the most effective recycling strategies. For example, in the case of an examined private coffee bean collecting

Table 5 The relationship between certificate ownership and the use of pesticides

\begin{tabular}{|c|c|c|c|c|c|}
\hline \multicolumn{6}{|l|}{ Count } \\
\hline & & \multicolumn{2}{|c|}{ Certification ownership } & \multirow[t]{2}{*}{ Total } & \\
\hline & & Yes & No & & \\
\hline \multirow[t]{2}{*}{ Pesticides } & No & 29 & 12 & 41 & \\
\hline & Yes & 37 & 59 & 96 & \\
\hline Total & & 66 & 71 & 137 & \\
\hline \multicolumn{6}{|l|}{ Chi-Square Tests } \\
\hline & Value & $d f$ & Asymp. Sig. (2-sided) & Exact Sig. (2-sided) & Exact Sig. (1-sided) \\
\hline Pearson Chi-Square & $11.924^{\mathrm{a}}$ & 1 & .001 & & \\
\hline Continuity Correction $^{\mathrm{b}}$ & 10.669 & 1 & .001 & & \\
\hline Likelihood Ratio & 12.170 & 1 & .000 & & \\
\hline Fisher's Exact Test & & & & .001 & .000 \\
\hline Linear-by-Linear Association & 11.837 & 1 & .001 & & \\
\hline$N$ of Valid Cases ${ }^{\mathrm{b}}$ & 137 & & & & \\
\hline
\end{tabular}

${ }^{a} 0$ cells $(.0 \%)$ have expected count less than 5 . The minimum expected count is 19.75

${ }^{\mathrm{b}}$ Computed only for a $2 \times 2$ table 
Table 6 The relationship between certificate ownership and planting shading trees

\begin{tabular}{|c|c|c|c|c|c|}
\hline \multicolumn{6}{|l|}{ Count } \\
\hline & & \multicolumn{2}{|c|}{ Certification ownership } & \multirow[t]{2}{*}{ Total } & \\
\hline & & Yes & No & & \\
\hline \multirow[t]{2}{*}{ Shade trees } & No & 33 & 45 & 78 & \\
\hline & Yes & 33 & 26 & 59 & \\
\hline Total & & 66 & 71 & 137 & \\
\hline \multicolumn{6}{|l|}{ Chi-Square Tests } \\
\hline & Value & df & Asymp. Sig. (2-sided) & Exact Sig. (2-sided) & Exact Sig. (1-sided) \\
\hline Pearson Chi-Square & $2.498^{\mathrm{a}}$ & 1 & .114 & & \\
\hline Continuity Correction ${ }^{b}$ & 1.982 & 1 & .159 & & \\
\hline Likelihood Ratio & 2.503 & 1 & .114 & & \\
\hline Fisher's Exact Test & & & & .124 & .080 \\
\hline Linear-by-Linear Association & 2.479 & 1 & .115 & & \\
\hline$N$ of Valid Cases ${ }^{b}$ & 137 & & & & \\
\hline
\end{tabular}

${ }^{a} 0$ cells $(.0 \%)$ have expected count less than 5 . The minimum expected count is 28.42

${ }^{\mathrm{b}}$ Computed only for a $2 \times 2$ table

enterprise, the manager said the packages of products were bought from other suppliers and the enterprise failed to address concerns about the origins of the material. Furthermore, they still often used new PVC sacks instead of packages made from environmentally friendly materials or recycled sacks.

Most production supervisors of the coffee processing company thought the company was currently paying more attention to its recycling policies. It mainly used packaging produced by Tetra Pak, a global environmentally friendly package producer. Moreover, in the factory and their main office, they separated production waste to dispose of or recycle it. One supervisor also stated that his company was now considering a training plan to guide farmers and local collectors to apply green supply chain and effective reverse logistics in the next financial year.

\section{Marketing, social attainment and corporate social responsibility}

From the statistical numbers in the survey, it is worth noting that only 66 out of 137 farmers had joined a sustainable certified coffee program, which accounted for $48.2 \%$ of those surveyed. These figures prove that few coffee growers have good knowledge of sustainable coffee. Furthermore, only $53.3 \%$ (73 of 137) of farmers said they often received support from local associations and $32.8 \%$ of those surveyed agreed that local associations and coffee companies often offered supportive scheme to encourage them.

The Chi square result in Table 9 showed a positive relationship between holding a certificate and support from local associations, with those farmers who held a sustainability certificate receiving support more often than those who did not have a certificate.

Table 7 The relationship between certificate ownership and the percentage of coffee sold directly

\begin{tabular}{|c|c|c|c|c|c|c|}
\hline \multicolumn{7}{|l|}{ Count } \\
\hline & & \multicolumn{4}{|c|}{ Percentage of your coffee sold directly } & \multirow[t]{2}{*}{ Total } \\
\hline & & $0-30 \%$ & $30-50 \%$ & $50-70 \%$ & $70-100 \%$ & \\
\hline \multirow[t]{2}{*}{ Certification ownership } & Yes & 14 & 10 & 18 & 24 & 66 \\
\hline & No & 52 & 7 & 5 & 7 & 71 \\
\hline Total & & 66 & 17 & 23 & 31 & 137 \\
\hline \multicolumn{7}{|l|}{ Chi-Square Tests } \\
\hline & Value & Df & \multicolumn{3}{|c|}{ Asymp. Sig. (2-sided) } & \\
\hline Pearson Chi-Square & $41.480^{\mathrm{a}}$ & 3 & \multicolumn{3}{|l|}{.000} & \\
\hline Likelihood Ratio & 44.025 & 3 & \multicolumn{3}{|l|}{.000} & \\
\hline Linear-by-Linear Association & 35.426 & 1 & \multicolumn{3}{|l|}{.000} & \\
\hline $\mathrm{N}$ of Valid Cases & 137 & & & & & \\
\hline
\end{tabular}

${ }^{a} 0$ cells $(.0 \%)$ have expected count less than 5 . The minimum expected count is 13.97 
Table 8 The relationship between certificate ownership and quality examination

\begin{tabular}{|c|c|c|c|c|c|c|}
\hline \multicolumn{7}{|l|}{ Count } \\
\hline & & \multicolumn{4}{|c|}{ Collectors or traders examine the planting process and quality frequently } & \multirow[t]{2}{*}{ Total } \\
\hline & & None & $1-2$ times/crop & $3-5$ times/crop & $>5$ times/crop & \\
\hline \multirow[t]{2}{*}{ Certification ownership } & Yes & 2 & 12 & 38 & 14 & 66 \\
\hline & No & 25 & 40 & 6 & 0 & 71 \\
\hline Total & & 27 & 52 & 44 & 14 & 137 \\
\hline \multicolumn{7}{|l|}{ Chi-Square Tests } \\
\hline & Value & Df & \multicolumn{3}{|c|}{ Asymp. Sig. (2-sided) } & \\
\hline Pearson Chi-Square & $71.855^{\mathrm{a}}$ & 3 & \multicolumn{3}{|l|}{.000} & \\
\hline Likelihood Ratio & 84.249 & 3 & \multicolumn{3}{|l|}{.000} & \\
\hline Linear-by-Linear Association & 63.461 & 1 & \multicolumn{3}{|l|}{.000} & \\
\hline $\mathrm{N}$ of Valid Cases & 137 & & & & & \\
\hline
\end{tabular}

${ }^{\mathrm{a}} 0$ cells $(.0 \%)$ have expected count less than 5 . The minimum expected count is 6.74

Furthermore, only 45 out of 137 surveyed farmers (32.8\%) agreed that local traders ensured they would take their output production, and 65 of asked farmers (47.5\%) said they did not join any cooperative farming group to protect their rights and their production. The Chi square test result in Table 10 shows that there is a positive relationship between the certification ownership and farmers who are members of any cooperative farming group, with group members having more knowledge about sustainable coffee than those who were not group members.

More importantly, $88.3 \%$ of farmers said coffee farming was their main source of income and 82.5\% (113 participants) said their family had suffered poverty as a result of fluctuating coffee prices in the past. Only 37 out of 137 (27\%) surveyed farmers said the average profit from coffee farms was more than 120 million Vietnamese dong per hectare per year. Their average total income is between 5 and 10 million Vietnamese dong per month (US\$250-500).
The Chi square result in Table 11 showed a positive relationship between the certification ownership and the profit from the coffee farms, with more people who held a sustainability certificate achieving profit over 100 million Vietnamese dong/ha/year than those who did not hold a certificate.

Most farmers support one to three dependant family members, including one or two children of school age. A total of $86.1 \%$ of farmers said they had to work between eight and $12 \mathrm{~h}$ daily to cultivate their crops.

Most famers had completed secondary education (27\%, or 37 people) or high school level $(49.6 \%$, or 68 people) - a very positive figure to show that they have a good basis to learn new advanced farming practices to participate in the certified coffee project. Only seven out of 137 surveyed participants were not willing to participate in training course about sustainable coffee development. The Chi square result in Table 12 showed a positive relationship between willingness to join a

Table 9 The relationship between certificate ownership and support from local association

\begin{tabular}{|c|c|c|c|c|c|c|}
\hline \multicolumn{7}{|l|}{ Count } \\
\hline & & \multicolumn{5}{|c|}{ Support from local associations } \\
\hline & & Never & Rarely & Often & Very often & Total \\
\hline \multirow[t]{2}{*}{ Certification ownership } & Yes & 8 & 2 & 41 & 15 & \\
\hline & No & 24 & 30 & 15 & 2 & 71 \\
\hline Total & & 32 & 32 & 56 & & 17 \\
\hline \multicolumn{7}{|l|}{ Chi-Square tests } \\
\hline & Value & Df & \multicolumn{2}{|c|}{ Asymp. Sig. (2-sided) } & & \\
\hline Pearson Chi-Square & $54.403^{a}$ & 3 & \multicolumn{2}{|l|}{.000} & & \\
\hline Likelihood Ratio & 61.388 & 3 & \multicolumn{2}{|l|}{.000} & & \\
\hline Linear-by-Linear Association & 37.179 & 1 & \multicolumn{2}{|l|}{.000} & & \\
\hline $\mathrm{N}$ of Valid Cases & 137 & & & & & \\
\hline
\end{tabular}

${ }^{a} 0$ cells (.0\%) have expected count less than 5 . The minimum expected count is 8.19 
Table 10 The relationship between knowledge about sustainable coffee and membership of a cooperative farming group

\begin{tabular}{|c|c|c|c|c|}
\hline \multicolumn{5}{|l|}{ Count } \\
\hline & & \multicolumn{2}{|c|}{ A member of any cooperative farming group } & \multirow[t]{2}{*}{ Total } \\
\hline & & No & Yes & \\
\hline \multirow[t]{3}{*}{ Knowledge about sustainable coffee area } & Never heard & 33 & 7 & 40 \\
\hline & Have heard but never joined & 29 & 37 & 66 \\
\hline & Have participated & 8 & 23 & 31 \\
\hline Total & & 70 & 67 & 137 \\
\hline \multicolumn{5}{|l|}{ Chi-Square tests } \\
\hline & Value & Df & \multicolumn{2}{|l|}{ Asymp. Sig. (2-sided) } \\
\hline Pearson Chi-Square & $25.074^{\mathrm{a}}$ & 2 & \multicolumn{2}{|l|}{.000} \\
\hline Likelihood Ratio & 26.832 & 2 & \multicolumn{2}{|l|}{.000} \\
\hline Linear-by-Linear Association & 23.485 & 1 & \multicolumn{2}{|l|}{.000} \\
\hline$N$ of Valid Cases & 137 & & & \\
\hline
\end{tabular}

sustainable coffee development program and the main sources of income of farmers.

Moreover, 132 out of 137 interviewees (96.4\%) agreed that they were willing to invest over 10 million Vietnamese dong to improve farming methods and certify their coffee. A total of 73 of 137 interviewees (53.3\%) said knowledge was the biggest challenge when it came to developing sustainable coffee. The role of woman in society was also emphasised, as $62 \%$ of farmers said women were fairly important in their family and $34.3 \%$ said women were very important.

The local collectors said they were trying to support local farmers. The certified coffee can be sold at 15-20\% higher price than normal coffee. And certification programs request rigorous certification criteria and monitor the conditions strictly annually. Under sustainability certification schemes, certified farmers tend to conserve soil and water resources. They also had found that although more coffee manufacturing companies and exporters to ensure a good output and price for farmers, sometimes there were risks that they were unable to manage. However, all the interviewees said they never tried to use financial tools or insurance to limit the risk.

The senior purchasing executive also explained that his company offered the best purchasing price for local farmers to support them in cultivating techniques. He agreed that his company also played a role as a bridge to connect famers and coffee manufacturing companies when the companies organised volunteer trips or supportive schemes, and suggested that the company supported poor farmers and collected old clothes for them.

The coffee company representative said the company would like to coordinate with government, certifying

Table 11 The relationship between certificate ownership and profit

\begin{tabular}{|c|c|c|c|c|c|c|}
\hline \multicolumn{7}{|l|}{ Count } \\
\hline & & \multicolumn{4}{|l|}{ Profit from the coffee farm } & \multirow[t]{2}{*}{ Total } \\
\hline & & $\begin{array}{l}<80 \text { million Vietnamese } \\
\text { dong/ha/year }\end{array}$ & $\begin{array}{l}\text { 80-100 million Vietnamese } \\
\text { dong/ha/year }\end{array}$ & $\begin{array}{l}\text { 100-120 million Vietnamese } \\
\text { dong/ha/year }\end{array}$ & $\begin{array}{l}\text { >120 million Vietnamese } \\
\text { dong/ha/year }\end{array}$ & \\
\hline \multirow{2}{*}{$\begin{array}{l}\text { Certification } \\
\text { ownership }\end{array}$} & Yes & 4 & 7 & 24 & 31 & 66 \\
\hline & No & 25 & 30 & 10 & 6 & 71 \\
\hline Total & & 29 & 37 & 34 & 37 & 137 \\
\hline \multicolumn{7}{|l|}{ Chi-Square Tests } \\
\hline & Value & Df & Asymp. Sig. (2-sided) & & & \\
\hline $\begin{array}{l}\text { Pearson } \\
\text { Chi-Square }\end{array}$ & $52.048^{\mathrm{a}}$ & 3 & .000 & & & \\
\hline Likelihood Ratio & 56.584 & 3 & .000 & & & \\
\hline $\begin{array}{l}\text { Linear-by-Linear } \\
\text { Association }\end{array}$ & 46.404 & 1 & .000 & & & \\
\hline $\mathrm{N}$ of Valid Cases & 137 & & & & & \\
\hline
\end{tabular}


Table 12 The relationship between main source of income and willingness to join

\begin{tabular}{|c|c|c|c|c|}
\hline \multicolumn{5}{|l|}{ Count } \\
\hline & & \multicolumn{2}{|c|}{ Is the coffee farm your main source of income? } & \multirow[t]{2}{*}{ Total } \\
\hline & & NO & YES & \\
\hline \multirow[t]{3}{*}{ Willing to join sustainable coffee development program } & No & 4 & 3 & 7 \\
\hline & Yes if have any supportive schemes & 6 & 79 & 85 \\
\hline & Yes for sure & 6 & 39 & 45 \\
\hline Total & & 16 & 121 & 137 \\
\hline \multicolumn{5}{|l|}{ Chi-Square Tests } \\
\hline & Value & Df & \multicolumn{2}{|l|}{ Asymp. Sig. (2-sided) } \\
\hline Pearson Chi-Square & $15.905^{\mathrm{a}}$ & 2 & \multicolumn{2}{|l|}{.000} \\
\hline Likelihood Ratio & 10.492 & 2 & \multicolumn{2}{|l|}{.005} \\
\hline Linear-by-Linear Association & 1.380 & 1 & \multicolumn{2}{|l|}{.240} \\
\hline $\mathrm{N}$ of Valid Cases & 137 & & & \\
\hline
\end{tabular}

${ }^{a} 1$ cells $(16.7 \%)$ have expected count less than 5 . The minimum expected count is .82

association and processing companies to organise free training for farmers to join sustainable coffee programs in order to enhance the output of certified coffee. The assistant brand manager of the coffee manufacturing company said her company worked closely with other companies to promote Buon Ma Thuot coffee to international and domestic market.

In analysing the opinions of interviewees, it is plausible to note that coffee processing companies in Vietnam aim to develop a sustainable society. They coordinate to organise a study encouragement fund for poor students, and offer higher purchasing price policies for local collectors to enable them buy coffee from local farmers at a higher price. In addition, by opening and expanding Coffee Village, one of those examined coffee process companies has created around 50 new positions per year for young people, and given them opportunities to promote their culture to tourists. This company also runs free English classes to teach staff to communicate with international tourists.

According to the production supervisor of this company, the factory in Buon Ma Thuot city currently offers jobs for approximately 270-300 workers, mainly from the local area. It also organises free training to teach farmers to cultivate their farms more effectively. The senior purchasing executive said the company was now planning to form a farmers' cooperative association and provide free processing machines for them with the purpose of cutting down the number of links in the supply chain network and increasing the return to farmers. He added that the company always emphasised the role of farmers and tried its best to improve their living standards. The company is coordinating with local authorities to develop a Regional Development Plan until 2025.
Logistic regression for the dependent variable 'certificate ownership'

The research used the surveyed data to run logistic regression to explain the relationship between the dependent variable 'Certificate ownership' and independent variables 'Productivity', 'Local support' and 'Experience'. It examined the probability of a farmer having a sustainability certificate with the given data of the independent variables. This helps sustainable coffee organisations to forecast whether or not a farmer will have a sustainable certificate with their current situation. The -2 Log likelihood is 72.26 , showing that the model is appropriate to develop and the percentage of correct prediction will be $89.1 \%$, which means it is a reliable formula (Table 13).

The formula of logistic regression is as follows:

$$
\begin{aligned}
-10.711 & +2.015^{*} \text { Productivity }+1.3^{*} \text { Local support } \\
& +0.934^{*} \text { Experience }
\end{aligned}
$$

Following the logistic model, if a farmer's productivity is around 4-6 tons/ha/year, the farmer has five years' experience and often receives local support, then he will have $\left(\mathrm{e}^{-10.711+2.015^{*} 3+1.3^{*} 3+0.934^{* 2}}\right) /\left(1+\mathrm{e}^{-10.711+2.015^{*} 3+}\right.$ $\left.1.3^{*} 3+0.934^{* 2}\right)=0.75 \sim 75 \%$ probability of having a sustainability certificate. Based on that model, we can consider which type of farmers should be focused on to develop the sustainability program, in order to help them to gain a sustainability certificate.

\section{Summary and conclusions}

Following the research, it is plausible to conclude that the development of sustainable coffee in Buon Ma Thuot City in particular, and in Vietnam in general, offers many opportunities but still encounters some difficulties that need to be overcome. By means of Chi-square analysis, 
Table 13 Logistic regression model. Source: Authors' own calculation

\begin{tabular}{|c|c|c|c|c|c|c|}
\hline \multicolumn{7}{|c|}{ Model Summary } \\
\hline Step & $\begin{array}{l}-2 \text { Log } \\
\text { likelihood }\end{array}$ & $\begin{array}{l}\text { Cox \& Snell R } \\
\text { Square }\end{array}$ & \multicolumn{4}{|c|}{ Nagelkerke R Square } \\
\hline 1 & $72.263^{\mathrm{a}}$ & .576 & \multicolumn{4}{|l|}{.768} \\
\hline \multicolumn{7}{|c|}{ Classification table ${ }^{b}$} \\
\hline & \multirow[t]{3}{*}{ Observed } & & \multicolumn{4}{|c|}{ Predicted } \\
\hline & & & \multicolumn{2}{|c|}{$\begin{array}{l}\text { Certification } \\
\text { ownership }\end{array}$} & \multicolumn{2}{|c|}{$\begin{array}{l}\text { Percentage } \\
\text { correct }\end{array}$} \\
\hline & & & NO & YES & & \\
\hline \multirow[t]{3}{*}{ Step 1} & \multirow{2}{*}{$\begin{array}{l}\text { Certification } \\
\text { ownership }\end{array}$} & No & 62 & 9 & 87.3 & \\
\hline & & Yes & 6 & 60 & 90.9 & \\
\hline & \multicolumn{2}{|c|}{ Overall Percentage } & & & \multicolumn{2}{|l|}{89.1} \\
\hline \multicolumn{7}{|c|}{ Variables in the Equation } \\
\hline & & B & S.E. & Wald & df Sig. & $\operatorname{Exp}(B$ \\
\hline \multirow[t]{4}{*}{ Step $1^{c}$} & PRODUCTIVITY & 2.015 & .450 & 20.064 & 1.000 & 7.502 \\
\hline & LOCALSUPPORT & 1.300 & .374 & 12.069 & 1.001 & 3.668 \\
\hline & EXPERIENCE & .934 & .378 & 6.110 & $1 \quad .013$ & 2.544 \\
\hline & Constant & -10.711 & 1.857 & 33.270 & $1 \quad .000$ & .000 \\
\hline
\end{tabular}

${ }^{a}$ Estimation terminated at iteration number 7 because parameter estimates changed by less than .001

${ }^{\mathrm{b}}$ The cut value is .500

'Variable(s) entered on step 1: PRODUCTIVITY, LOCALSUPPORT, and EXPERIENCE Because of the Sig of the variable data are less than 0.05 so we can deny the hypothesis that $\beta_{\text {productivity }}=\beta_{\text {local support }}=\beta_{\text {experience }}=0$ that means they have the statistical meaning

the positive impacts of sustainable coffee programs on the sustainable coffee supply chain management are confirmed. Certified farmers also perform higher levels of adoption of improved production practices. Environmental management, social attainment and corporate social responsibility are becoming the main concern of coffee processing companies but there is limited evidence of large-scale support from them to local farmers. Thus, the success of the improvement depends mainly on cooperation among stakeholders, both in the public and private sectors. They have to coordinate closely to improve current farming practices, and then manage the supply chain network as well as reverse logistic issues along with consider strategies to support sustainable development. The government should also consider more effective policies and laws to encourage investment in sustainable coffee production, and expand the market for this product. Besides, the premium price for certified coffee is known as approximately $10-20 \%$ higher than the normal price. A positive relationship between certification ownership and higher economic profit is shown in the research; however, future researches should measure and prove the financial benefits for farmers to persuade them to join sustainable programs. Another contribution that future research should examine is the productivity benefit when farmers change from planting normal coffee to certified coffee. Researchers should provide them with guidance to help them manage the quality of their coffee farms. Finally, the logistic regression model is suggested to help government and sustainable coffee programs choose farmers with proper conditions in order to achieve more success.

It is confirmed that sustainable coffee schemes should be enhanced thanks to their benefits. However, there are some limitations of this study that future research should consider. Due to the limitations of time and experience, the researchers were unable to study a larger sample, which could generate a more accurate result. In addition, the research did not measure the financial impacts of the sustainable coffee program.

\section{Acknowledgements \\ The authors sincerely thank you all farmers and participants from coffee manufacturing companies who willing to complete the surveys and interview to complete this research. \\ Funding \\ No funding. \\ Availability of data and materials Not applicable. \\ Authors' contributions \\ GNTN, conduted the field work and analysed data; TS, provided theoretical framework and methodology. Both authors read and approved the final manuscript.}

Ethics approval and consent to participate

Not applicable.

Consent for publication

Not applicable.

\section{Competing interests}

The authors declare that they have no competing interests.

\section{Publisher's Note}

Springer Nature remains neutral with regard to jurisdictional claims in published maps and institutional affiliations.

\section{Author details}

${ }^{1}$ Becamex Business School, Eastern International University, Binh Duong, Vietnam. ${ }^{2}$ Griffith Business School, Griffith University, Brisbane, Queensland, Australia.

Received: 12 May 2017 Accepted: 10 December 2017

Published online: 09 January 2018

\section{References}

Acosta-Alba, l., \& van der Werf, H. (2011). The use of reference values in indicatorbased methods for the environmental assessment of agricultural systems. Sustainability, 3, 424-442.

Acs, S., Berentsen, P. B., \& Huirne, R. B. (2005). Modelling conventional and organic farming: A literature review. Wageningen Journal of Life Sciences, 53(1), 1-18.

Ageron, B., Gunasekaran, A., \& Spalanzani, A. (2012). Sustainable supply management: An empirical study. International Journal of Production Economics, 140(1), 168-182.

Aguilera, R. V., \& Jackson, T. (2003). The cross-national diversity of corporate governance: Dimensions and determinants. Academy of Management Review, 28(3), 447-466. 
Alblas, A., Kristian Peters, K., \& Hans Wortmann, J. (2014). Fuzzy sustainability incentives in new product development. International Journal of Operations \& Production Management, 34(4), 513-545.

Ali, M., \& Byerlee, D. (2002). Productivity growth and resource degradation in Pakistan's Punjab: A decomposition analysis. Economic Development and Cultural Change, 50(4), 839-863.

Altieri, M., \& Koohafkan, P. (2008). Enduring farms: Climate change, smallholders and traditional farming communities, Environment and development. Penang: Third World Network

Barney, J. B. (1991). The resource based view of strategy: Origins, implications, and prospects. Journal of Management, 17, 97-211.

Beamon, B. M. (1999). Designing the green supply chain. Logistics Information Management, 12(4), 332-342.

Bennett, M., \& Franzel, S. (2013). Can organic and resource-conserving agriculture improve livelihoods? A synthesis. International Journal of Agricultural Sustainability, 11(3), 193-215.

Beske, P., Koplin, J., \& Seuring, S. (2006). The use of environmental and social standards by German first-tier suppliers of the Volkswagen AG. Corporate Social Responsibility and Environmental Management, 15(2), 63-75.

Bowen, F. E., Cousins, P. D., Lamming, R. C., \& Faruk, A. C. (2001). The role of supply management capabilities in green supply. Production and Operations Management, 10(2), 174-189.

Brammer, S., Hoejmose, S., \& Millington, A. (2011). Managing Sustainable Global Supply Chain: Framework and Best Practices. Ontario: Network for Business Sustainability. Retrieved 4 11, 2017, from https://nbs.net/p/executive-reportsustainable-global-supply-chains-0150d33f-f10e-4294-9648-ab58b84f067c.

Campbell, J. L. (2007). Why would corporations behave in socially responsible ways? An institutional theory of corporate social responsibility. Academy of Management Review, 32(3), 946-967.

Carter, C. (2005). Purchasing social responsibility and firm performance: The key mediating roles of organizational learning and supplier performance. International Journal of Physical Distribution \& Logistics Management, 35(3), 177-194.

Carter, C. R., \& Rogers, D. S. (2008). A framework of sustainable supply chain management: Moving toward new theory. International Journal of Physical Distribution \& Logistics Management, 38(5), 360-387.

Carter, C., \& Easton, P. (2011). Sustainable supply chain management: Evolution and future directions. International Journal of Physical Distribution \& Logistics Management, 41(1), 46-62.

Chakraborty, A. (2012). Crop diversification in Murshidabad district, West Bengal: A spatiotemporal analysis. International Journal of Physics, and Social Sciences, 2(7), 393-403.

Conroy, M. (2007). Branded! How the Certification Revolution is Transforming Global Corporations. Gabriola Island: New society. Publishers.

Crowdera, D. W., \& Reganold, J. P. (2015). Financial competitiveness of organic agriculture on a global scale. Proceedings of the National Academy of Sciences of the United States of America, 112(24), 7611-7616.

Cuganesan, S., Guthrie, J., \& Ward, L. (2010). Examining CSR disclosure strategies within the Australian food and beverage industry. Accounting Forum, 34(3-4), 169-118.

Dasgupta, S., Deichmann, U., Meisner, C. M., \& Wheeler, D. (2003). The poverty/ environment nexus in Cambodia and Lao People's Democratic Republic. World Bank Policy Research Working Paper No, 2960, 1-40.

D'haeze, D., Deckers, J., Raes, D., \& Loi, H. V. (2005). Environmental and socioeconomic impacts of institutional reforms on the agricultural sector of Vietnam: Land suitability assessment for Robusta coffee in the Dak Gan region. Agriculture, Ecosystems \& Environment, 105(1-2), 59-76.

DiMaggio, P. J., \& Powell, W. W. (1983). The iron cage revisited: Institutional isomorphism and collective rationality in organizational fields. American Sociological Review, 48(2), 147-160.

Farina, E. M., \& Reardon, T. (2000). Agrifood grades and standards in the extended Mercosur: Their role in changing Agrifood system. American Journal of Agricultural Economics, 82(5), 1170-1176.

Font, X., Tapper, R., Schwartz, K., \& Kornilaki, M. (2008). Sustainable supply chain management in tourism. Business Strategy and the Environment, 17(4), 260-271

Freeman, R. E. (1984). Strategic management: A stakeholder approach. Boston: Pitman. Galdeano-Gómez, E., Aznar-Sánchez, J., Pérez-Mesa, J., \& Piedra-Muñoz, L. (2017). Exploring synergies among agricultural sustainability dimensions: An empirical study on farming system in Almería (Southeast Spain). Ecological Economics, 99-109.

Giovannucci, D., \& Koekoek, F. J. (2003). The state of sustainable coffee: A study of 12 major markets. UNCTAD: Cali - Colombia.
Giovannuccia, D., \& Ponte, S. (2005). Standards as a new form of social contract? Sustainability initiatives in the coffee industry. Food Policy, 30(3), 284-301.

Halberg, N., Panneerselvam, P., \& Treyer, S. (2015). Eco-functional intensification and food security: Synergy or compromise? Sustainable Agriculture Research, 4(3), 126-139.

Hassini, E., Surti, C., \& Searcy, C. (2012). A literature review and a case study of sustainable supply chains with a focus on metrics. International Journal of Production Economics, 140(1), 69-82.

Hayati, D., Ranjbar, Z., \& Karami, E. (2010). Measuring agricultural sustainability. In D. Hayati, Z. Ranjbar, \& E. Karami (Eds.), Biodiversity, biofuels, Agroforestry and conservation agriculture (pp. 73-100). Dordrecht: Springer.

Hoejmose, S., \& Adrien-Kirby, A. (2013). Socially and environmentally responsible procurement: A literature review and future research agenda of a managerial issue in the 21st century. International Journal of Operations \& Production Management, 33(5), 589-621.

Hsu, C.-C., Tan, K.-C., \& Zailani, S. H. (2016). Strategic orientations sustainable supply chain initiatives, and reverse logistics: Empirical evidence from an emerging market. International Journal of Operations \& Production Management, 36(1), 86-110.

lakovou, E., Vlachos, D., Achillas, C., \& Anastasiadis, F. (2014). Design of sustainable supply chains for the agrifood sector: A holistic research framework. Agricultural Engineering International: CIGR Journal. Special issue 2014: Agrifood and biomass, 1-10.

International Bank for Reconstruction and Development/ The World Bank. (2011). Vietnam coffee supply chain risk assessment. Hanoi: Worldbank.

International Coffee Organisation (ICO). (2015). IDH Presentation at ICO. International coffee organisation (ICO). Retrieved April 11, 2017, from http:// dev.ico.org/documents/cy2014-15/Presentations/5th-forum-6-idh-e.pdf.

Ipsos Business Consulting. (2013). Vietnam's coffee industry. Ipsos Business Consulting. Retrieved April 11, 2017, from http://www.ipsosconsulting.com/ pdf/Ipsos-Research-Note-Vietnam-Coffee.pdf.

Jaffee, S., Siegel, P., \& Andrews, C. (2010). Rapid Agricultural Supply Chain Risk Assessment: A Conceptual Framework. Agriculture and Rural Development Discussion Paper 47. World Bank. Retrieved December 16, 2017, from http:// siteresources.worldbank.org/INTARD/Resources/RapApRisk_combined_web. pdf.

Jarosz, L. (2000). Understanding agri-food networks as social relations. Agriculture and Human Values, 17, 279-283.

Johns, N., \& Pine, R. (2002). Consumer behaviour in the food service industry: A review. International Journal of Hospitality Management, 21(2), 119-134.

Kilcher, L. (2007). How organic agriculture contributes to sustainable development. Journal of Agriculture and Rural Development in the Tropics and Subtropics, 89, 31-49.

Kolk, A., \& Tulder, R. v. (2010). International business, corporate social responsibility and sustainable development. International Business Review, 19(2), 119-125.

Kong, D. (2012). Does corporate social responsibility matter in the food industry? Evidence from a nature experiment in China. Food Policy, 37(3), 323-334.

Le, H. V. (2013). Training Need Assessment of Vietnamese Coffee Farmers Report. Sustainable Community Assistance Network. Retrieved April 11, 2017, from http://scanprogram.org/wp-content/uploads/2013/09/Report-training-needassessment-final-EN_1.pdf.

Lentijo, G. M., \& Hostetler, M. (2011). Evaluating Certified Coffee Programs. The Institute of Food and Agricultural Sciences, University of Florida. Retrieved April 11, 2017, from http://edis.ifas.ufl.edu/uw351.

Maignan, I., \& Ralston, D. A. (2002). Corporate social responsibility in Europe and the U.S.: Insights from businesses self-presentations. Journal of International Business Studies, 33(3), 497-514.

Malik, D., \& Singh, I. (2002). Crop diversification-an economic analysis. Indian Journal of Agricultural Research, 36(1), 61-64.

Markley, M. J., \& Davis, L. (2007). Exploring future competitive advantage through sustainable supply chains. International Journal of Physical Distribution \& Logistics Management, 37(9), 763-774.

Marsh, A. (2007). Diversification by smallholder farmers: Viet Nam Robusta coffee. The Food and Agriculture Organisation of United Nation. Retrieved April 11, 2017, from http://www.fao.org/docrep/016/ap301e/ap301e.pdf.

Matten, D., \& Moon, J. (2008). "Implicit" and "explicit" CSR: A conceptual framework for a comparative understanding of corporate social responsibility. Academy of Management Review, 33(2), 404-424.

Minot, N. (1998). Competitiveness of Food Processing in Vietnam: A Study of the Rice, Coffee, Seafood, and Fruits and Vegetables Subsectors Ministry of Planning and Investment Vietnam and United Nations Industrial 
Development Organization Vietnam. Retrieved April 11, 2017, http://agro.gov. vn/images/2007/04/food.pdf.

Mistiaen, V. (2012). A better future is percolating for Vietnam's coffee. The Guardian. Retrieved April 11, 2017, from https://www.theguardian.com/ global-development/poverty-matters/2012/mar/26/better-future-vietnamcoffee-growth

Mohd, N. F. (2010). Sustainable supply chains: A study of interaction among the enablers. Business Process Management Journal, 16(3), 508-529.

Morali, O., \& Searcy, C. (2012). A review of sustainable supply chain management practices in Canada. Journal of Business Ethics, 117, 635-658.

Negatu, W., \& Parikh, A. (1999). The impact of perception and other factors on the adoption of agricultural Technology in the Moret and Jiru Woreda (district) of Ethiopia. Agricultural Economics, 21, 205-216.

Nemes, N. (2009). Comparative analysis of organic and non-organic farming systems: A critical assessment of farm profitability. Rome: Food and Agriculture Organization of the United Nation.

Nguyen, V. T. (2010). UTZ CERTIFIED's Productivity-focused Program Helps Vietnam Coffee Industry Grow. National Coffee Association of U.S.A. Retrieved April 11, 2017, from http://www.prweb.com/releases/utz_certified/ coffee_conference/prweb3753764.htm.

Nguyen, V. T., \& Yapwattanaphuna, C. (2015). Banana farmers' adoption of sustainable agriculture practices in the Vietnam uplands: The case of Quang Tri Province. Agriculture and Agricultural Science Procedia, 5, 67-74.

Pfeffer, J., \& Salancik, G. (1978). The external control of organizations: A resource dependence perspective. New York: Harper \& Row.

Pokharel, S., \& Mutha, A. (2009). Perspectives in reverse logistics: A review. Resources, Conservation and Recycling, 53(4), 175-182.

Pretty, J., Toulmin, C., \& Williams, S. (2011). Sustainable intensification in African agriculture. International Journal of Agricultural Sustainability, 9(1), 5-24.

Prokesch, S. (2010). The Sustainable Supply Chain. Harvard Business Review. Retrieved April 11, 2017, from Harvard business review: https://hbr.org/2010/ 10/the-sustainable-supply-chain

Rahmann, G. (2011). Biodiversity and organic farming: What do we know? Landbauforschung Volkenrode, 61(3), 189-208.

Ramesh, P., Panwar, N., Singh, A., Ramana, S., Yadav, S., Shrivastava, R., \& Rao, A. (2010). Status of organic farming in India. Current Science, 98(9), 1190-1194.

Roekel, J., Willems, S., \& Boselie, D. M. (2002). Agri-Supply Chain Management To Stimulate Cross-Border Trade in Developing Countries and Emerging Economies. The World Bank. Retrieved April 11, 2017, from http:// siteresources.worldbank.org/INTARD/825826-1111044795683/20424530/ AgriSupplyChainMang_finalversion.pdf.

Sarkis, J. (2009). Convincing industry that there is value in environmentally supply chains. Problems of Sustainable Development, 4(1), 61-64.

Sarkis, J., Zhu, Q., \& Lai, K. (2011). An organizational theoretic review of green supply chain management literature. International Journal of Production Economics, 130(1), 1-15.

Schmitter, P., Dercon, G., Hilger, T., Thi Le Ha, T., Huu Thanh, N., Lam, N... . Cadisch, G. (2010). Sediment induced soil spatial variation in paddy fields of Northwest Vietnam. Geoderma, 155(3-4), 298-307.

Seuring, S., \& Müller, M. (2008). From a literature review to a conceptual framework for sustainable supply chain management. Journal of Cleaner Production, 16(15), 1699-1710.

TechnoServe. (2013). Vietnam a business case for sustainable coffee production. TechnoServe. Retrieved April 11, 2017, from www.sustainablecoffeeprogram. com/site/getfile.php?id=211.

The Voice Of Vietnam. (2014). Vietnam ascending to world's largest coffee exporter. The Voice Of Vietnam. Retrieved December 16, 2016, from http:// english.vov.vn/Economy/Trade/Vietnam-ascending-to-worlds-largest-coffeeexporter/279633.vov.

Theocharopoulos, A., Melfou, K., \& Papanagiotou, E. (2012). Analysis of decision making process for the adoption of sustainable farming systems: The case of peach farmers in Greece. American-Eurasian Journal of Sustainable Agriculture, 6(1), 24-32.

Vietnam Briefing. (2014). Vietnam Coffee Production to Decline in 2015. Vietnam Briefing Magazine. Retrieved April 11, 2017, from http://www.vietnambriefing.com/news/vietnam-coffee-production-decline-2015.html/.

Vietnam Customs. (2015). Trade Analysis. Vietnam Customs. Retrieved April 11, 2017, from http://www.customs.gov.vn/Lists/EnglishStatistics/ScheduledData. aspx?Group=Trade\%20analysis\&language $=$ en-US.

Voice of Vietnam. (2017). Th ph cà phê Ban Mê $r \quad n$ ràng trư c ngày $h$ il n. Voice of Vietnam (vov.vn). Retrieved December 16, 2017, from: http:// vov.vn/kinh-te/thu-phu-ca-phe-ban-me-ron-rang-truoc-ngay-hoi-lon-600310. vov.

Von Wirén-Lehr, S. (2001). Sustainability in agriculture - An evaluation of principal goal-oriented concepts to close the gap between theory and practice. Agriculture, Ecosystems \& Environment, 84(2), 115-129.

Wahyudi, T., \& Jati, M. (2012). Challenges of Sustainable Coffee Certification in Indonesia. International Coffee Organisation. Retrieved April 11, 2017 from http://www.ico.org/event_pdfs/seminar-certification/certification-iccri-paper. pdf.

Walker, H., Di Sisto, L., \& McBain, D. (2008). Drivers and barriers to environmental supply chain management practices: Lessons from the public and private sectors. Journal of Purchasing and Supply Management, 14(1), 69-85.

Wang, Z., \& Sarkis, J. (2013). Investigating the relationship of sustainable supply chain management with corporate financial performance. International Journal of Productivity and Performance Management, 62(8), 871-888.

Ward, M., \& Nguyen, T. H. (2014). Vietnam coffee annual 2014. Hanoi: U.S. Department Of Agriculture.

Webster, P. (1999). The challenge of sustainability at the farm level: Presidential address. Journal of Agricultural Economics, 50(3), 371-387.

World Commission on Environment and Development. (1987). Our Common Future. Oxford and. New York: Oxford University Press.

Zhu, Q., \& Sarkis, J. (2007). The moderating effects of institutional pressures on emergent green supply chain practices and performance. International Journal of Production Research, 45(18-19), 4333-4355.

Zulfiqara, F., \& Zulfiqara, F. (2017). Agricultural sustainability assessment at provincial level in Pakistan. Land Use Policy, 68, 492-502.

\section{Submit your manuscript to a SpringerOpen ${ }^{\circ}$ journal and benefit from:}

- Convenient online submission

- Rigorous peer review

- Open access: articles freely available online

- High visibility within the field

- Retaining the copyright to your article

Submit your next manuscript at $\gg$ springeropen.com 